\title{
Pragmatic Strategies and Linguistic Structures in Making 'Suggestions': Towards Comprehensive Taxonomies
}

\author{
Hossein Abolfathiasl \\ Department of Language and Humanities Education, Faculty of Educational Studies \\ Universiti Putra Malaysia, 43400 UPM SERDANG, Selangor, Malaysia \\ Tel: +60176812703 \\ E-mail: hoseinabolfathi@gmail.com \\ Ain Nadzimah Abdullah (corresponding author) \\ Department of English Language, Faculty of Modern Languages \& Communication \\ Universiti Putra Malaysia, 43400 UPM SERDANG, Selangor, Malaysia

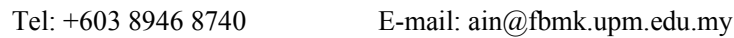

Received: 01-07-2013

Accepted: 30-09-2013

Published: 01-11-2013

doi:10.7575/aiac.ijalel.v.2n.6p.236

URL: http://dx.doi.org/10.7575/aiac.ijalel.v.2n.6p.236

\begin{abstract}
This paper analyses and upgrades taxonomies of strategies and structures for the speech act of suggesting based on existing taxonomies and classifications in the pragmatics research literature. Previous studies have focused mainly on linguistic structures used to perform the speech act of suggesting. Thus, there seems to be a need to provide a more comprehensive set of taxonomies for structures as well as strategies that can be used in EFL/ESL classrooms and for research on the speech act of suggesting. To this end, the speech act of suggesting is defined first and the features of this speech act are discussed. Second, the most recent classifications proposed for structures and linguistic realization strategies for suggestions were analysed and contrasted and a more comprehensive taxonomy of structures and linguistic realization strategies is provided, based on previous taxonomies. Finally, taxonomy of politeness strategies in making suggestions are provided, based on recent studies in cross-cultural pragmatics research.
\end{abstract}

Keywords: speech act of suggesting, pragmatic strategy, linguistic structure, taxonomy

\section{Introduction}

Research on second language pragmatics acquisition or development has typically studied various speech acts in different cultural and pedagogical settings. Researchers have tried to develop classifications for structures and strategies used to perform different speech acts through cross-cultural and cross-linguistic studies in recent years. These classifications and taxonomies can be used by other researchers in pragmatics research, especially in interventional studies. They can also comprise teaching material in ESL/EFL classrooms. Suggesting a face-threatening speech act which has not been studied extensively in pragmatics research. Few taxonomies and classifications have been proposed for suggesting strategies and structures, thus far, yet there is not a comprehensive set of taxonomies of the structures and strategies involved in making L2 suggestions. In this paper, an improved taxonomy of linguistic structures and strategies for making suggestions will be provided by investigating and merging the existing taxonomies and a set of politeness strategies will be provided to make a more comprehensive set of taxonomies for 'suggestions'. Suggesting is a type of directive speech act in which, according to Searle (1976), the speaker's aim is to get the hearer to commit themselves to some future course of action. Based on this definition, many researchers regard suggesting as a directive speech act (Brown \& Levinson, 1978; Holmes, 1983; Schmidt \& Richards, 1985; Banerjee \& Carrell, 1988). Banerjee and Carrell (1988) define suggestion as "an utterance that the speaker intends the hearer to perceive as a directive to do something that will be to the hearer's benefit" (p. 319). In Bach and Harnish's (1979) definition of directives, it is implied that the speaker's intention in an utterance must be taken as a reason for the hearer's future action. The necessary interaction between the speaker and the hearer is one of the features that distinguishes directives from other groups of speech acts. According to Trosborg (1995), the hearer's future action is part of the speaker's intention only in the case of directives. Thomas (1995) also believes that both the speaker and the hearer should be considered in producing directive speech acts. According to Brown and Levinson's (1987) politeness theory, suggesting is regarded as a face-threatening act (FTA) since the interlocutor who makes the suggestion somehow intrudes into the hearer's world through performing an act to get the latter to do something. Banerjee and Carrell (1988) regard suggestions as an imposition on the hearer by affronting their negative face. In making suggestions, several factors should be taken into account, such as the degree of embarrassment in the situation, the urgency of suggestion, and the social distance and power between the interlocutors (Brown \& Levinson, 1987). Regarding these factors and the extent to which a situation 
can be more or less threatening, the speaker might try to employ some politeness strategies to soften or mitigate the speech act, and thus prevent or minimize the chances of the hearer's being offended (Martinez-Flor, 2005). Successful speech act performance depends upon interlocutor possession of socio-cultural and sociolinguistic knowledge (Cohen, 1996). Sociocultural knowledge determines which speech act to perform and when it is appropriate in a given situation. Sociolinguistic knowledge, also referred to as pragmalinguistic knowledge (Bardovi-Harlig, 1999; Kasper \& Rose, 2002; Thomas, 1983), determines the linguistic realization of whichever speech act is appropriate in a specific situation. This type of knowledge encompasses the knowledge about linguistic and strategic resources available for communicating through performing a speech act. According to Kasper (1997), these resources include pragmatic strategies, routines, and a variety of linguistic structures that can intensify or mitigate communicative acts. Thus, an extensive repertoire of linguistic structures and knowledge of these forms is an essential component of speech act performance.

\section{Taxonomies of Linguistic Structures and Strategies}

In an attempt to compile a more comprehensive list of linguistic structures and also strategies used for making suggestions, previous studies and taxonomies provided for these structures in the literature were reviewed. The linguistic structures used for making suggestions provided by Jiang (2006) and Martinez-Flor (2005) were found to be the most recent and comprehensive lists available. The list of structures provided by Jiang (2006) is based on corpus data analysis, thus it reflects real-life usage of the structures well. A new list of structures and strategies may be created by first comparing/contrasting and then merging the classifications mentioned above in order to provide a more inclusive taxonomy of linguistic structures and pragmatic structures used to make suggestions.

Using naturally occurring data from office hours and study groups from the TOEFL 2000 Spoken and Written Academic Language Corpus (data from US universities) by Biber et al. (2002) and generating a list of possible and most commonly used structures for making suggestions from various sources, Jiang (2006) conducted a concordance search to determine each structure's frequency of occurrence and also the register differences between office hours and study groups (from the corpus data) in terms of using the structures. In the list provided by Jiang (2006), the structures are classified into nine categories, based on their grammatical features, including Let's..., modals and semi-modals, Wh-questions, conditionals, performatives, pseudo-cleft structures, extraposed to-clauses, yes-no questions, and imperatives. A list of the structures with examples for each category is illustrated in Table 1.

Table 1. List of structures used for making suggestions (Jiang, 2006)

\begin{tabular}{|l|l|}
\hline LINGUISTIC STRUCTURE & EXAMPLE \\
\hline Let's... & \\
\hline Modals and semi-modals & $\begin{array}{l}\text { You need to... } \\
\text { You should... } \\
\text { You must... }\end{array}$ \\
\hline Wh-questions & $\begin{array}{l}\text { Why don't you....? } \\
\text { How about...? }\end{array}$ \\
\hline Conditionals & $\begin{array}{l}\text { If I were... } \\
\text { If you... }\end{array}$ \\
\hline Performatives & suggest/recommend/suggestion/recommendation/proposal \\
\hline Pseudo-cleft structures & $\begin{array}{l}\text { One thing you could do is.... } \\
\text { All...is... } \\
\text { What...is... }\end{array}$ \\
\hline Extraposed to-clauses & $\begin{array}{l}\text { It might be. . to... } \\
\text { It never hurts/...won't hurt... to... }\end{array}$ \\
\hline Yes-no questions & $\begin{array}{l}\text { Have you thought of/about ....? } \\
\text { Would you consider ...? }\end{array}$ \\
\hline Imperatives & Try... Write... \\
\hline
\end{tabular}

Martinez-Flor (2005) also proposed a taxonomy of linguistic realization strategies for suggestions, including three main types: direct, conventionalized and indirect forms. The direct strategies, in which the speaker clearly states what he/she means, are performed using performative verbs, a noun of suggestion, imperatives and negative imperatives. It has been argued that the use of performative verbs to make suggestions is not very common in everyday life, regarding its high level of directness. However, Martinez-Flor's (2004) findings show that native speakers sometimes use performative verbs to make suggestions in formal situations. The use of a noun of suggestion is regarded as a very direct type of suggestion, as well (Tsui, 1994). Making suggestions using imperatives is regarded as the most direct and impolite form of suggesting (Edmonson \& House, 1981; Hinkel, 1997; Koike, 1997; Martinez-Flor, 2005) since they carry the most literal pragmatic force. 
The second type of forms used to make suggestions in Martinez-Flor's taxonomy is conventionalized forms. These forms are not as direct as the first type of suggestions and the illocutionary force indicator appears in the utterance so that the hearer can understand the speaker's intentions behind the suggestion. The conventionalized type includes the use of specific formulae (i.e., interrogative forms), expressions of possibility or probability, the use of the verbs should and need, and the use of conditionals.

The third type of linguistic suggesting strategy is referred to as indirect suggestion (Martinez-Flor, 2005). In these forms of suggestions, there is no indicator of illocutionary force in the utterance so the speaker's intention should be inferred by the hearer. Using various impersonal forms, and also hints, has been regarded as two ways of making indirect suggestions (Bardovi-Harlig \& Hartford, 1996; Hinkel, 1994, 1997; Koike, 1994). The linguistic realization strategies for suggestions taxonomy provided by Martinez-Flor (2005) is shown in Table 2, below.

Table Error! No text of specified style in document.. Taxonomy of Suggestion Linguistic Realization Strategies (Martinez-Flor, 2005)

\begin{tabular}{|c|c|c|}
\hline TYPE & STRATEGY & EXAMPLE \\
\hline \multirow[t]{4}{*}{ DIRECT } & Performative verb & $\begin{array}{l}\text { I suggest that you... } \\
\text { I advise you to ... } \\
\text { I recommend that you ... }\end{array}$ \\
\hline & Noun of suggestion & My suggestion would be... \\
\hline & Imperative & Try using... \\
\hline & Negative imperative & Don't trv to... \\
\hline \multirow[t]{5}{*}{$\begin{array}{l}\text { CONVENTIONALISED } \\
\text { FORMS }\end{array}$} & $\begin{array}{l}\text { Specific formulae (interrogative } \\
\text { forms) }\end{array}$ & $\begin{array}{l}\text { Why don't you...? } \\
\text { How about...? } \\
\text { What about...? } \\
\text { Have you thought about...? }\end{array}$ \\
\hline & Possibility/probability & $\begin{array}{l}\text { You can... You could... You may... You } \\
\text { might... }\end{array}$ \\
\hline & Should & You should... \\
\hline & Need & You need to... \\
\hline & Conditional & If I were you, I would... \\
\hline \multirow[t]{2}{*}{ INDIRECT } & Impersonal & $\begin{array}{l}\text { One thing (that you can do) would be } \\
\text { Here's one possibility: ... } \\
\text { There are a number of options that } \\
\text { you... } \\
\text { It would be helpful if you... } \\
\text { It might be better to... } \\
\text { A good idea would be... } \\
\text { It would be nice if... }\end{array}$ \\
\hline & Hints & I've heard that... \\
\hline
\end{tabular}

\section{Comparing and Contrasting Taxonomies}

Although classifications of linguistic forms used for making suggestions provided by Jiang (2006) and Martinez-Flor (2005) overlap to some extent, there are differences between the two classifications that should be taken into account. The list, provided by Jiang (2006), includes let's as one of the commonly used structures for making suggestions. However, Martinez-Flor's (2005) classification does not include this structure as the focus of her categorization was on the type of suggestions in which only the hearer benefits from performing the suggestion. So it is possible to add let's to the direct suggestion category to improve the classification of suggesting structures. The 'modals and semi-modals' category in Jiang's list of structures can be contrasted with the 'possibility and probability' plus 'should' and 'need' strategies under 'conventionalized forms' in Martinez-Flor's classification. The category of 'modals and semi-modals' seems to be more inclusive than Martinez-Flor's categories in that the former includes 'have to' as a very commonly used structure to make suggestions (Jiang, 2006), while this structure is absent in the latter categorization. Therefore, the structure 'have to' should be considered in the improved list of structures as well. This can be done by using Jiang's 'modals and semi-modals' category in the new version of structures. One might decide to break down this category into 'possibility/probability', 'should', 'need to', and 'have to' sub-categories to facilitate their use by researchers and teachers in L2 research and classrooms. Moreover, Jiang has focused on two types of suggestions made using 'yes/no questions' and 'wh-questions', while Martinez-Flor has put these two categories under the single category of specific formulae or interrogative forms. Presenting 'interrogative forms' as two separate categories of 'yes/no questions' and 'wh-questions' seems to be more helpful and easier to understand and use for L2 pragmatics researchers and teachers. With the same token, the 'pseudo-cleft structures' and 'extra-posed to-clauses' categories in Jiang's list of structures 
seem to explain the 'impersonal' strategies, presented by Martinez-Flor in a more detailed and easier-to-understand way.

Martinez-Flor's (2005) taxonomy, on the other hand, provides three suggestion types, as well, which can be regarded as one of its advantages over Jiang's list of structures, which does not extend beyond linguistic structures. Moreover, Martinez-Flor has categorized 'performative verbs' and 'noun of suggestion' as two separate strategies in making suggestions, while Jiang has presented them together under the category of 'performatives'. Although 'performatives' can be an umbrella word for both verb and noun forms used for making suggestions, separating the performative verbs and nouns of suggestion, as provided by Martinez-Flor, would make the taxonomy easier to understand and use by teachers, learners, and researchers. Furthermore, Martinez-Flor's classification includes another category called 'hints' under 'indirect type' suggestions. Jiang's list of structures, however, lacks this category. Another issue to be discussed here is that the classification of 'strategies' of Martinez-Flor (2005) is ambiguous. The categories such as 'performative verbs', 'interrogative forms', 'should' and 'need' have been classified as suggesting 'strategies', while they are categorized as 'linguistic structures' in Jiang (2006).

\section{A Proposal for an Improved Taxonomy}

$\mathrm{Li}$ (2010) refers to three types of suggestion strategies regarding the directness level of a suggestion, i.e., direct strategies, conventionally indirect strategies (conventionalized forms in Martinez-Flor, 2005) and non-conventionally indirect strategies, such as hints. Regarding Li's (2010) and Martinez-Flor's (2005) classifications of pragmatic suggesting strategies and also Jiang's (2006) classification of linguistic structures, the strategies in the upgraded classification of strategies and structures would be classified as direct, conventionally indirect and non-conventionally indirect strategies, followed by a 'linguistic structures' category and examples for each structure type. As we can see in Table 3, merging the taxonomies analysed in this paper would provide a more comprehensive taxonomy of linguistic structures and strategies used for performing the speech act of suggesting. This classification of strategies and structures seem to be more inclusive and easier to understand and use. The categories of strategies or structures which were absent in either classification, such as let's in Martinez-Flor's taxonomy and hints in Jiang's classification have been integrated into the proposed taxonomy.

Table 3. The improved classification of linguistic structures and strategies used for making suggestions

\begin{tabular}{|c|c|c|}
\hline $\begin{array}{l}\text { SUGGESTING } \\
\text { STRATEGY }\end{array}$ & $\begin{array}{l}\text { LINGUISTIC } \\
\text { STRUCTURE }\end{array}$ & EXAMPLES \\
\hline \multirow[t]{3}{*}{ DIRECT } & $\begin{array}{l}\text { Performatives: Performative } \\
\text { Verbs \& Noun of } \\
\text { Suggestion }\end{array}$ & $\begin{array}{l}\text { I suggest/recommend/propose } \\
\text { My suggestion/advice is that... }\end{array}$ \\
\hline & $\begin{array}{l}\text { Imperatives \& Negative } \\
\text { imperatives }\end{array}$ & $\begin{array}{l}\text { Ask them about... } \\
\text { Don't try to use... }\end{array}$ \\
\hline & Let's... & Let's work together on the project. \\
\hline \multirow[t]{3}{*}{$\begin{array}{l}\text { NON- } \\
\text { CONVENTIONALLY } \\
\text { INDIRECT }\end{array}$} & $\begin{array}{l}\text { Pseudo-cleft Structures } \\
\text { (impersonal) }\end{array}$ & $\begin{array}{l}\text { All...is... } \\
\text { One thing you could do is... } \\
\text { One important thing to keep in mind is... }\end{array}$ \\
\hline & $\begin{array}{l}\text { Extra-posed to-clauses } \\
\text { (impersonal) }\end{array}$ & $\begin{array}{l}\text { It might (not) be...to... } \\
\text { It is ...to... }\end{array}$ \\
\hline & Hints & I've read/heard that... \\
\hline \multirow[t]{4}{*}{$\begin{array}{l}\text { CONVENTIONALLY } \\
\text { INDIRECT }\end{array}$} & Modals \& Semi-modals & $\begin{array}{l}\text { You... have to/need to/should (shouldn't)/ought } \\
\text { to/can/could/might/had better... }\end{array}$ \\
\hline & Conditionals & $\begin{array}{l}\text { If you... } \\
\text { If I were you }\end{array}$ \\
\hline & $\begin{array}{l}\text { Wh-Questions } \\
\text { (interrogative) }\end{array}$ & $\begin{array}{l}\text { Why don’t you...? } \\
\text { How about...? } \\
\text { Why not...? }\end{array}$ \\
\hline & $\begin{array}{l}\text { Yes-no Questions } \\
\text { (interrogative) }\end{array}$ & $\begin{array}{l}\text { Would you consider...? } \\
\text { Have you thought of...? }\end{array}$ \\
\hline
\end{tabular}

\section{Politeness Strategies in Making Suggestions}

In addition to linguistic structures used for the speech act of suggesting, the politeness strategies that that are chosen to make suggestions appropriately should also be taken into account. For the purpose of the current study, the most recent cross-cultural studies on pragmatic strategies used for making suggestions were reviewed, as well, to identify a list of politeness strategies used for performing the speech act of suggesting. Of the previous comparative studies done on suggesting strategies and classifications provided, Li's (2010) classification of suggesting strategies is used in the study for the following reasons. First, Li's (2010) study has provided classifications for politeness strategies. Second, it is the most recent comparative study addressing suggesting strategies and has taken into account previous studies, as well, e.g., the Cross-cultural Speech Act Realization Project (CCSARP) scheme (Blum-Kulka, 1989). 
According to $\mathrm{Li}$ (2010), there are three aspects of pragmatic strategies in making suggestions which should be considered and analysed: perspective, directness and politeness. Politeness strategies are believed to be the central issue in linguistic performance. Pragmatic strategies used for suggestions are examined in terms of politeness, as well. Suggestion is regarded as a face-threatening act (Banerjee \& Carrell, 1988; Brown \& Levinson, 1987), thus an interlocutor makes a suggestion in one of two ways: either as bald on record, without any redressive action, or with redressive actions to lessen the face-threatening force. There are two types of redressive actions: internal and external. Internal redressive actions are indicated inside the suggestion utterance, while external actions are linguistic elements or supportive moves that exist outside the suggestion utterance in order to mitigate the intrusive force of making the suggestion. Internal redressive actions include subjectivizers, appealers, tense forms, cajolers, politeness markers, subjunctives and downtoners. External redressive actions comprise grounders, politeness markers, preparatory, downgrading commitment and imposition minimizers. A list of linguistic forms used for internal and external redressive actions is provided below, followed by examples of their usage in suggestions adopted from Li (2010, pp. 604-5) in Table 3.

Internal redressive actions include the following:

(1) Subjectivizers are elements used by the speaker to expresses the idea that the suggestion only represents his/her subjective opinion, thus lowering the assertive force of it.

(2) Appealers are elements used by the speaker to appeal to the hearer's benevolent understanding.

(3) In English, past tense forms can be used with present time reference to downgrade the assertive force.

(4) Cajolers are conventionalized speech items in which their semantic contents are of little transparent relevance to their discourse meaning to downgrade the assertive force of a suggestion.

(5) Politeness markers are elements added to a suggestion aiming for cooperation from the hearer.

(6) Subjunctive forms, such as might, can be used by speakers to soften the imposition force in making suggestions.

(7) Downtoners are sentential or propositional modifiers for modifying the impact the suggestion is likely to have on the hearer.

External redressive actions include the following:

(1) Grounders refer to any reasons, explanations or justifications that the speaker gives for his/her suggestion.

(2) External politeness markers are any elements inserted to suggestions aiming for cooperation from the hearer.

(3) Preparators are any moves in which the speaker asks about the potential possibility of carrying out the suggestion, or asks for the hearer's permission to make a suggestion in order to prepare the hearer for ensuing the suggestion without giving away the content of the speech act.

(4) Downgrading commitments are modifiers that the speaker employs to minimize the degree of his/her commitment to a suggestion.

(5) Imposition minimizers are elements through which the speaker tries to reduce the imposition placed on the hearer by his/her suggestion.

Table 4. Politeness strategies in making suggestions adapted from Li (2010)

\begin{tabular}{|l|l|l|}
\hline $\begin{array}{l}\text { POLITENESS } \\
\text { STRATEGY }\end{array}$ & ACTION & EXAMPLE \\
\hline $\begin{array}{l}\text { INTERNAL REDRESSIVE } \\
\text { ACTION }\end{array}$ & Subjectivizers & I think it'd be better to go to the movies. \\
\cline { 2 - 3 } & Appealers & Let's do it tomorrow, okay? \\
\cline { 2 - 3 } & Past tense & I wanted to get him a book for present. \\
\cline { 2 - 3 } & Cajolers & You know, I think you should take that course. \\
\cline { 2 - 3 } & Politeness markers & Let's try once more, if you don't mind. \\
\cline { 2 - 3 } $\begin{array}{l}\text { EXTERNAL REDRESSIVE } \\
\text { ACTION }\end{array}$ & Subjunctive forms & It'd be better if we finished it today. \\
\cline { 2 - 3 } & Downtoners & You should perhaps move to another place. \\
\cline { 2 - 3 } & $\begin{array}{l}\text { External politeness } \\
\text { markers }\end{array}$ & $\begin{array}{l}\text { How about going to the beach. I bet we will have } a \\
\text { great time there. }\end{array}$ \\
\cline { 2 - 3 } & Preparators & $\begin{array}{l}\text { You'd better drop that course. What do you think? } \\
\text { some time off work. }\end{array}$ \\
\cline { 2 - 3 } & $\begin{array}{l}\text { Downgrading } \\
\text { commitments }\end{array}$ & $\begin{array}{l}\text { I'm not too sure but I think you need to check it } \\
\text { online. }\end{array}$ \\
\hline
\end{tabular}




\section{Conclusions}

This paper was an attempt to move towards providing more comprehensive taxonomies and classifications of strategies and structures used for making the speech act of suggesting. Although some taxonomies and lists of suggesting strategies and structures have been proposed by researchers, mainly in cross-cultural studies, bringing these taxonomies together, discussing them and presenting them as a more comprehensive set of classifications seems valuable for facilitating their use by researchers and L2 teachers/learners in pragmatics studies and instructional endeavors. Therefore, the latest taxonomies of linguistic structures and strategies used to make suggestions were merged into a single compilation of structures and linguistic realization strategies. Since politeness strategies are considered essential in successful performance of face-threatening speech acts such as suggestions, a taxonomy of politeness strategies based on the latest research on pragmatic strategies of suggesting was also presented in an attempt to provide a framework of all strategies and structures for making suggestions that can be used by teachers, teacher trainers, researchers, and material developers. These taxonomies are expected to be evaluated and improved upon to more inclusively reflect the strategies and structures used in performing suggestions in future studies.

\section{References}

Bach, K., \& Harnish, R. M. (1979). Linguistic communication and speech acts. Cambridge, MA: MIT Press

Banerjee, J. \& Carrell, P. L. (1988). Tuck in your shirt, you squid: Suggestions in ESL. Language Learning, 38, 313364.

Bardovi-Harlig, K. (1996). Pragmatics and language teaching: Bringing pragmatics and pedagogy together. In L. F. Bouton (Ed.), Pragmatics and Language Learning (pp. 21-39). Urbana-Champaign, IL: University of Illinois Press.

Bardovi-Harlig, K. \& Hartford, B. S. (1996). Input in an institutional setting. Studies in Second Language Acquisition 18: 171-188.

Blum-Kulka, Sh. (1989). Playing it safe: The role of conventionality in indirectness. In S. Blum-Kulka, J. House, G. Kasper (Eds.), Cross-cultural Pragmatics: Requests and Apologies (pp. 37-70). Norwood, NJ: Ablex Publishing.

Brown, P. \& Levinson, S. C. (1987). Politeness: Some universals in language use. Cambridge, United Kingdom: Cambridge University Press.

Cohen, A. D. (1996). Developing the ability to perform speech acts. Studies in Second Language Acquisition, 18(2), 253-267.

Hinkel, E. (1994). Appropriateness of advice as L2 solidarity strategy. RELC Journal, 25, 71-93.

Hinkel, E. (1997). Appropriateness of advice: DCT and multiple choice data. Applied Linguistics, 18(1), 1-26

Holmes, J. (1983). The structure of teachers' directive. In J. C. Richards, R. W. Schmidt (Eds.), Language and Communication. Cambridge, United Kingdom: Cambridge University Press.

Jiang, X. (2006). Suggestions: What should ESL students know? System, 34, 36-54.

Kasper, G. (1997). Can pragmatic competence be taught? Second Language Teaching and Curriculum Center, University of Hawaii. Retrieved December 6, 2003, from http://www.nflrc.hawaii.edu/NetWorks/NW06/default.html

Kasper, G., \& Rose, K. R. (2002). Pragmatic Development in a Second Language. A supplement to Language Learning 52 (Suppl. 1).

Koike, D. A. (1994). Negation in Spanish and English suggestions and requests: Mitigating effects? Journal of Pragmatics, 21, 513-526.

Li, E. S. (2010). Making suggestions: A contrastive study of young Hong Kong and Australian students. Journal of Pragmatics, 42, 598-616.

Martinez-Flor, A. (2005). A theoretical review of the speech act of suggesting: Towards a taxonomy for its use in FLT. Revista Alicantina de Estudios Ingleses, 18, 167-187

Schmidt, R., \& Richards, J. C. (1985). Speech acts and L2 learning. In J. Richards (Ed.), The context of language teaching (pp. 100-128). Cambridge, United Kingdom: Cambridge University Press.

Searle, J. R. (1969). Speech acts: An essay in the philosophy of language. Cambridge, United Kingdom: Cambridge University Press.

Thomas, J. (1983). Cross-cultural pragmatic failure. Applied Linguistics, 4, 91-112.

Trosborg, A. (1995). Interlanguage pragmatics. Requests, complaints and apologies. Berlin, Germany: Mouton de Gruyter. 